International Journal of Current Micro6iology and Applied Sciences

ISSN: 2319-7706 Volume 9 Number 9 (2020)

Journal homepage: http://www.ijcmas.com

Original Research Article

https://doi.org/10.20546/ijcmas.2020.909.453

\title{
Role of Sea Plant Extracts in Growth and Development of Mulberry for Sustainable Sericulture
}

\author{
M. P. Yeshika ${ }^{1 *}$, K. G. Banuprakash ${ }^{1}$, N. Nagaraju ${ }^{2}$, Manjunath Gowda ${ }^{1}$, \\ K. Murali Mohan ${ }^{3}$ and K. S. Vinoda ${ }^{4}$ \\ ${ }^{1}$ Department of Sericulture, ${ }^{2}$ Department of Plant Pathology, ${ }^{3}$ Department of Agricultural \\ Entomology, UAS, GKVK, Bangalore - 560065, Karnataka, India \\ ${ }^{4}$ Department of Silkworm Genetics \& Breeding, College of Sericulture, \\ Chintamani - 563125, Karnataka, India \\ *Corresponding author
}

Keywords

Sea plant extract, Kappaphycus sp., Mulberry

Article Info

Accepted:

28 August 2020

Available Online:

10 September 2020

\section{A B S T R A C T}

Field experiment was conducted for the evaluation of potentiality in sea plant extracts got from Kappaphycus sp. in boosting the growth, leaf quality and yield of mulberry leaves. Foliar sprays of different concentrations of sea plant extract were sprayed on the mulberry plants at different intervals of time. It was found that foliar application of sea plant extract from LBS 13 at $1.5 \mathrm{ml} / \mathrm{l}$ at $45^{\text {th }}$ day after pruning enhanced the leaf yield per plant by $308.81 \mathrm{~g} / \mathrm{pl}$, average plant height by $150.42 \mathrm{~cm}$, number of shoots present (14.32) and leaves per plant (400 leaves per plant) along with chlorophyll content when compared to control. Results of the present study indicate that application of seaweed extract significantly increases both quality and quantity of mulberry leaves.

\section{Introduction}

Mulberry (Morus alba L.) foliage is the only food for the silkworm, Bombyx mori L. It has been analysed that, nearly 70 per cent of the silk proteins present in the cocoon are derived from mulberry leaves. Hence, its necessary for the silkworms to be fed with good quality mulberry leaves which in turn will be responsible for successful cocoon production (Vijaya et al., 2009). Though synthetic chemicals, fertilizers, pesticides, herbicides, growth promoters and other inputs escalate the productivity of mulberry, they do adversely affect the ecosystem. Continuous production of mulberry crop for a long time 
will result in gradual reduction of leaf yield and also its quality (Rashmi et al., 2009). In the current global scenario it is very much needed to adopt eco-friendly agricultural practices for a better and sustainable Sericulture.

Organic farming can be stated as the remedy to the ills of modern chemical agriculture. Many viable options have to be explored to meet the increasing demand of organic inputs day by day and one of the option among those is the use of sea plant extract serving as source of nutrient for the plants (Zodape, 2001). Extracts procured from marine sea plants could be used to replace the synthetic chemicals as they contain high levels of organic matter, micro nutrients, vitamins, fatty acids in them along with growth regulators such as Auxins, Cytokinin and Gibberellic acid. Unlike, the extensively used synthetic chemicals, extracts which are derived from the sea plants are known to be biodegradable, nontoxic to ecosystem, nonpolluting and non-hazardous to the environment (Khan et al., 2009). Apart from being eco friendly their beneficial effects to the growing plants include enhanced root growth, leaf growth of the plant, increased yield, tolerance to different plant stress conditions and increased resistance to pathogens and pests. Maria Victorial Rani and Evanjaline, 2015 explained that the application of sea plant extract from $K$. alvaerezii boosted the shoot length, number of leaves per plant, leaf area, circumference of growing stem, root growth of the plant and total biomass in mulberry. Application of different sea plant extracts were also found beneficial in other crops like black gram (Ganesh et al., 2015) and chilly (Arunkumar et al., 2015 and Jayasinghe et al., 2016).Therefore, in the present research it is proposed to study the effect of cultivated sea plant (Kappaphycus sp.) extract on growth and development of mulberry.

\section{Materials and Methods}

\section{Experimental layout}

The experimental design was set up at the Department of Sericulture, University of Agriculture Sciences, Bangalore with well established mulberry garden of $\mathrm{V}_{1}$ variety. Package of practices suggested for irrigated condition of mulberry was followed. Recommended levels of fertilizer application (300:140:140 NPK kg/ha/year) was applied along with 20 tonnes of FYM/ha (Dandin et al., 2003). The field experiment done was laid according to the Randomized Block Design with 14 treatments and 3 replication each.

\section{Treatment details}

Cultivated tropical sea plant extracts of Kappaphycus sp. (a.i. sulfated galactans) with four different formulations were procured from Sea6 Energy Pvt. Ltd.(Centre for Cellular and Molecular Platforms, Bangalore) viz., LBD3, LBD12, LBS6 and LBS13. The sea plant extracts selected were used as foliar sprays in freshly pruned mulberry garden at three different concentrations on 21 and 30 Days After Pruning (DAP) and care was taken to ensure that there was no drifting of chemicals due to wind by holding a polythene cover along the treated plants while spraying (Table 1).

\section{Observations taken}

Plant height $(\mathrm{cm})$, number of shoots per plant and number of leaves per plant were calculated on $45^{\text {th }}$ Day After Pruning (DAP). The shoot height was measured from the base of the plant to the tip of the fully opened leaf of all the shoots of labelled plants and mean shoot height was calculated.

Mean shoot height $=\frac{\text { Total shoot height }}{\text { Number of shoots }}$ 
Leaf area was calculated at 45 DAP from the plants using a leaf area meter. Five labelled plants were maintained exclusively for estimation of leaf yield. Leaves harvested individually plant wise and their yield was recorded. The total leaf yield obtained from net plot was recorded as the leaf yield and expressed in g/plant which was recorded on $45^{\text {th }}$ DAP.

Protein content of mulberry leaves was analysed by Lowry's method (Lowry et al., 1951). The quantity of protein (mg) per gram of fresh weight is expressed in the evaluation. Biochemical parameters like Chlorophyll 'a', Chlorophyll 'b' and total Chlorophyll were quantified by following the method of Arnon (1949) using 3 replications of all the treatments and the control. Chlorophyll from the leaves were extracted in 80 per cent ethyl alcohol and the absorption rate was at $663 \mathrm{~nm}$ and $645 \mathrm{~nm}$ in the spectrophotometer. The chlorophyll absorption co-efficient was calculated by using the formula given below.

Chlorophyll a $\quad=\quad[(12.7 \times$ OD663 $)-$
$(2.69 \times$ OD645)] 0.1
Chlorophyll b $b=[(22.9 \times$ OD645) -
$(4.68 \times$ OD663)] 0.1

Total Chlorophyll = Chlorophyll 'a' + Chlorophyll ' $b$ '

The data obtained were statistically analysed by using Web Based Agricultural Statistics Software Package WASP 2.0 (Web Agri Stat Package) and also using one way ANOVA (Randomized Block Design and Completely random design) and CRD (Complete Random Design) with DMRT (Duncan's Multiple Range Test) to determine significant differences among different treatments.

\section{Results and Discussion}

Plant height of mulberry exhibited significant difference among the treatments wherein the highest mulberry plant growth was noticed in the treatment LBS13 at $1.5 \mathrm{ml} / 1(150.42 \mathrm{~cm})$ and the shortest mulberry plant was observed in the treatment LBS6 at $1 \mathrm{ml} / 1(113.11 \mathrm{~cm})$. LBS13 at $1.5 \mathrm{ml} / \mathrm{l}$ was on par with LBS13 at 1 $\mathrm{ml} / 1 \quad(145.98 \mathrm{~cm})$ and LBS6 at $0.5 \mathrm{ml} / \mathrm{l}$ $(140.86 \mathrm{~cm})$. The treatments LBS13 at 0.5 $\mathrm{ml} / \mathrm{l}(140.39 \mathrm{~cm}), \mathrm{LBD} 12$ at $1.5 \mathrm{ml} / \mathrm{l}(138.53$ $\mathrm{cm})$ and LBD3 at $6 \mathrm{ml} / \mathrm{l}(138.31 \mathrm{~cm})$ were on par with each other as well as exhibited higher growth of mulberry when compared to that of the absolute control $(128.25 \mathrm{~cm})$ and distilled water control $(127.27 \mathrm{~cm})$. Sea plant products provide growth-stimulating activities, and the use of them as bio stimulants in crop production is well established. Biostimulants are defined as "materials, other than fertilizers, which promote plant growth when applied in small quantities" and they are also referred to as "metabolic enhancers" (Zhang and Schmidt 1997).

The treatment LBS13 at $1.5 \mathrm{ml} / \mathrm{l}$ was found to enhance the number of shoot per plant by (14.32) as well as number of leaves per plant was found to be more in it (400 leaves / pl). The least number of shoot per plant and number of leaves per plant were found in the mulberry plants treated with LBS6 at $1 \mathrm{ml} / \mathrm{l}$ 12.83 and 199.67 respectively. The treatments LBS13 at $1 \mathrm{ml} / 1$ (14.12), LBS13 at $0.5 \mathrm{ml} / 1$ (14.05), LBS6 at $0.5 \mathrm{ml} / 1$ (14.06) and LBD12 at $1.5 \mathrm{ml} / \mathrm{l}(14.05)$ also exhibited better and on par results regarding number of shoots per plant in mulberry ecosystem and proved to be better than the control (13.05). Higher number of leaves per plant were also found in the treatments LBS13 at $1 \mathrm{ml} / 1$ (398.67), LBS13 at $0.5 \mathrm{ml} / 1$ (389.33) and LBS6 at $0.5 \mathrm{ml} / 1$ (385) which were on par with each other as well as better than absolute control (216).

The treatment LBS13 at $1.5 \mathrm{ml} / 1$ recorded larger leaf area of about $(135.68 \mathrm{~cm} 2)$ on $45^{\text {th }}$ DAP, followed by the treatment LBS6 at 0.5 $\mathrm{ml} / 1(121.72 \mathrm{~cm} 2)$ and LBS13 at $1 \mathrm{ml} / \mathrm{l}$ 
$(116.47 \mathrm{~cm} 2)$. Lesser leaf area was recorded in the treatment LBS6 at $1 \mathrm{ml} / \mathrm{l}$ (65.90). Since the growth of mulberry treated with LBS6 at $1 \mathrm{ml} / \mathrm{l}$ was less, lesser leaf area can be observed in the plants.

Greater yield potential of $(308.81 \mathrm{~g} / \mathrm{pl})$ was recorded in LBS13 at $1.5 \mathrm{ml} / \mathrm{l}$ treated mulberry plants which was followed by LBS13 at $1 \mathrm{ml} / 1(289.53 \mathrm{~g} / \mathrm{pl}), \mathrm{LBS} 13$ at 0.5 $\mathrm{ml} / \mathrm{l}(282.72 \mathrm{~g} / \mathrm{pl})$, LBS6 at $0.5 \mathrm{ml} / \mathrm{l}(284.78$ $\mathrm{g} / \mathrm{pl})$ and LBD3 at $2 \mathrm{ml} / \mathrm{l}(284.53 \mathrm{~g} / \mathrm{pl})$. The mulberry plants treated with LBS6 at $1 \mathrm{ml} / \mathrm{l}$ exhibited lesser yield of $220.59 \mathrm{~g} / \mathrm{pl}$ when compared to that of the control (228.61 $\mathrm{g} / \mathrm{pl}$ ).Present findings strengthens the observations of Tiwary et al., 2014 who reported that leaf yield was found to increase when lesser concentration of sea plant extract $(0.5 \mathrm{ml} / \mathrm{l})$ from Dictyota dichotoma and Kappaphycus alvaerezii were applied as foliar sprays. Maria Victorial Rani and Evanjaline, 2015 also observed that application of the marine sea plant extract from $K$. alvaerezii boosted the shoot length of plant, number of leaves per plant, leaf area, circumference of stem, root growth and total biomass by $107 \%$, $100 \%, 135 \%, 91 \%, 140 \%$ and $140 \%$ respectively in mulberry at third month after the application in comparison with control.

Crop yield in plants are enhanced due to - and microelement nutrients, amino acids, vitamins, cytokinins, auxins, and abscisic acid (ABA)-like growth substances affect cellular metabolism in sea plant extract treated plants (Durand et al., 2003; Stirk et al., 2003; Ordog et al., 2004). Yield increases in seaweedtreated plants are thought to be associated with the hormonal substances present in the extracts, especially cytokinins (Featonby Smith 1984). Cytokinins in vegetative plant organs are associated with nutrient partitioning, whereas in reproductive organs, high levels of cytokinins may be linked with nutrient mobilization (Table 2 and 3).

Table.1

\begin{tabular}{|l|l|}
\hline Treatments & Description \\
\hline $\mathbf{T}_{\mathbf{1}}$ & Foliar application of LBD3 at $2 \mathrm{ml} / 1$ \\
\hline $\mathbf{T}_{\mathbf{2}}$ & Foliar application of LBD3 at $4 \mathrm{ml} / 1$ \\
\hline $\mathbf{T}_{\mathbf{3}}$ & Foliar application of LBD3 at $6 \mathrm{ml} / 1$ \\
\hline $\mathbf{T}_{\mathbf{4}}$ & Foliar application of LBD12 at $0.5 \mathrm{ml} / 1$ \\
\hline $\mathbf{T}_{\mathbf{5}}$ & Foliar application of LBD12 at $1 \mathrm{ml} / 1$ \\
\hline $\mathbf{T}_{\mathbf{6}}$ & Foliar application of LBD12 at $1.5 \mathrm{ml} / 1$ \\
\hline $\mathbf{T}_{\mathbf{7}}$ & Foliar application of LBS6 at $0.5 \mathrm{ml} / 1$ \\
\hline $\mathbf{T}_{\mathbf{8}}$ & Foliar application of LBS6 at $1 \mathrm{ml} / 1$ \\
\hline $\mathbf{T}_{\mathbf{9}}$ & Foliar application of LBS6 at $1.5 \mathrm{ml} / 1$ \\
\hline $\mathbf{T}_{\mathbf{1 0}}$ & Foliar application of LBS13 at $0.5 \mathrm{ml} / 1$ \\
\hline $\mathbf{T}_{\mathbf{1 1}}$ & Foliar application of LBS13 at $1 \mathrm{ml} / 1$ \\
\hline $\mathbf{T}_{\mathbf{1 2}}$ & Foliar application of LBS13 at $1.5 \mathrm{ml} / 1$ \\
\hline $\mathbf{T}_{\mathbf{1 3}}$ & Distilled water control \\
\hline $\mathbf{T}_{\mathbf{1 4}}$ & Control \\
\hline & LBD=Liquid Bio Defence: LBS= Liquid Bio Stimulant \\
\hline
\end{tabular}


Table.2 Growth attributes of sea plant extract treated mulberry at 45 Days After Pruning

\begin{tabular}{|c|c|c|c|c|c|c|}
\hline \multicolumn{2}{|r|}{ Treatments } & \multirow{2}{*}{$\begin{array}{c}\begin{array}{c}\text { Plant } \\
\text { height }(\mathbf{c m})\end{array} \\
128.37^{\mathrm{def}}\end{array}$} & \multirow{2}{*}{$\begin{array}{c}\begin{array}{c}\text { No. of } \\
\text { shoots / } \\
\text { plant }\end{array} \\
14.05^{\mathrm{b}}\end{array}$} & \multirow{2}{*}{$\begin{array}{c}\begin{array}{c}\text { No. of } \\
\text { leaves / } \\
\text { plant }\end{array} \\
374.00^{\mathrm{d}}\end{array}$} & \multirow{2}{*}{$\begin{array}{c}\begin{array}{c}\text { Leaf } \\
\text { area } \\
\left(\mathbf{c m}^{2}\right)\end{array} \\
106.47^{\mathrm{d}}\end{array}$} & \multirow{2}{*}{$\begin{array}{c}\begin{array}{c}\text { Leaf } \\
\text { yield / } \\
\text { plant }(\mathrm{g})\end{array} \\
284.53^{\mathrm{bc}}\end{array}$} \\
\hline$T_{1}$ & Foliar application of LBD3 at $2 \mathrm{ml} / \mathrm{l}$ & & & & & \\
\hline $\mathbf{T}_{2}$ & Foliar application of LBD3 at $4 \mathrm{ml} / \mathrm{l}$ & $134.94^{\text {cde }}$ & $13.26^{\mathrm{cd}}$ & $232.33^{\mathrm{g}}$ & $84.07^{\mathrm{f}}$ & $258.18^{d}$ \\
\hline $\mathbf{T}_{3}$ & Foliar application of LBD3 at $6 \mathrm{ml} / \mathrm{l}$ & $138.31^{\mathrm{bc}}$ & $13.5^{\mathrm{d}}$ & $325.33^{\mathrm{f}}$ & $103.69^{d}$ & $236.87^{g}$ \\
\hline $\mathbf{T}_{4}$ & Foliar application of LBD12 at $0.5 \mathrm{ml} / 1$ & $128.41 \mathrm{~d}^{\mathrm{ef}}$ & $13.04^{\mathrm{de}}$ & $203.67^{\mathrm{j}}$ & $84.50^{\mathrm{f}}$ & $238.67^{\mathrm{g}}$ \\
\hline$T_{5}$ & Foliar application of LBD12 at $1 \mathrm{ml} / \mathrm{l}$ & $137.73 b^{\mathrm{cd}}$ & $13.50^{\mathrm{c}}$ & $225.00^{\mathrm{h}}$ & $97.53^{\mathrm{e}}$ & $245.74^{\mathrm{e}}$ \\
\hline$T_{6}$ & Foliar application of LBD12 at $1.5 \mathrm{ml} / 1$ & $138.53^{\mathrm{bc}}$ & $14.05^{\mathrm{b}}$ & $356.33^{\mathrm{e}}$ & $107.60^{\mathrm{d}}$ & $253.59^{d}$ \\
\hline $\mathbf{T}_{7}$ & Foliar application of LBS6 at $0.5 \mathrm{ml} / \mathrm{l}$ & $140.86^{\mathrm{abc}}$ & $14.06^{\mathrm{b}}$ & $385.0^{\mathrm{bc}}$ & $121.72^{\mathrm{b}}$ & $284.78^{\mathrm{bc}}$ \\
\hline $\mathbf{T}_{8}$ & Foliar application of LBS6 at $1 \mathrm{ml} / \mathrm{l}$ & $113.11^{\mathrm{g}}$ & $12.83^{\mathrm{ef}}$ & $199.67^{\mathrm{j}}$ & $65.90^{\mathrm{h}}$ & $220.59^{\mathrm{i}}$ \\
\hline $\mathbf{T}_{9}$ & Foliar application of LBS6 at $1.5 \mathrm{ml} / \mathrm{l}$ & $121.53 \mathrm{f}^{\mathrm{g}}$ & $13.25^{\mathrm{d}}$ & $381.00^{\mathrm{c}}$ & $74.27^{\mathrm{g}}$ & $245.12^{\mathrm{ef}}$ \\
\hline$T_{10}$ & Foliar application of LBS13 at $0.5 \mathrm{ml} / 1$ & $140.39^{\mathrm{bc}}$ & $14.05^{\mathrm{b}}$ & $389.33^{\mathrm{b}}$ & $102.85^{\mathrm{d}}$ & $282.72^{\mathrm{c}}$ \\
\hline$T_{11}$ & Foliar application of LBS13 at $1 \mathrm{ml} / 1$ & $145.98^{\mathrm{ab}}$ & $14.12^{\mathrm{ab}}$ & $398.67^{\mathrm{a}}$ & $116.47^{\mathrm{c}}$ & $289.53^{b}$ \\
\hline$T_{12}$ & Foliar application of LBS13 at $1.5 \mathrm{ml} / \mathrm{l}$ & $150.42^{\mathrm{a}}$ & $14.32^{\mathrm{a}}$ & $400.00^{\mathrm{a}}$ & $135.68^{\mathrm{a}}$ & $308.81^{\mathrm{a}}$ \\
\hline$T_{13}$ & Distilled water control & $127.27^{\mathrm{ef}}$ & $13.13^{\mathrm{d}}$ & $222.00^{\mathrm{h}}$ & $77.29^{\mathrm{g}}$ & $239.74^{\mathrm{fg}}$ \\
\hline \multirow[t]{4}{*}{$T_{14}$} & Control & $128.25^{\mathrm{def}}$ & $13.05^{\mathrm{de}}$ & $216.00^{\mathrm{i}}$ & $74.72^{\mathrm{g}}$ & $228.61^{\mathrm{h}}$ \\
\hline & F-test & $*$ & $*$ & $*$ & $*$ & $*$ \\
\hline & SE.m \pm & 3.39 & 0.084 & 1.654 & 1.794 & 1.856 \\
\hline & $\mathrm{CD}$ at $5 \%$ & 9.851 & 0.244 & 4.808 & 5.215 & 5.395 \\
\hline
\end{tabular}

*Significant at $5 \%$, DAS- Days after spraying. 
Table.3 Leaf quality parameters of sea plant extract treated mulberry at 45 Days After Pruning

\begin{tabular}{|c|c|c|c|c|c|}
\hline \multicolumn{2}{|r|}{ Treatments } & \multirow{2}{*}{$\begin{array}{c}\begin{array}{c}\text { Crude } \\
\text { protein } \\
(\%)\end{array} \\
37.21^{\mathrm{a}}\end{array}$} & \multirow{2}{*}{$\begin{array}{c}\begin{array}{c}\text { Chl a } \\
(\mathrm{mg} / \mathrm{g})\end{array} \\
1.26^{\mathrm{i}}\end{array}$} & \multirow{2}{*}{$\begin{array}{c}\begin{array}{c}\text { Chl b } \\
\text { (mg/g) }\end{array} \\
0.42^{\mathrm{g}}\end{array}$} & \multirow{2}{*}{$\begin{array}{c}\begin{array}{c}\text { Total Chl } \\
\text { (mg/g) }\end{array} \\
1.70^{\mathrm{k}}\end{array}$} \\
\hline$T_{1}$ & $\begin{array}{l}\text { Foliar application of LBD3 at } \\
2 \mathrm{ml} / 1\end{array}$ & & & & \\
\hline $\mathbf{T}_{2}$ & $\begin{array}{l}\text { Foliar application of LBD3 at } \\
4 \mathrm{ml} / \mathrm{l}\end{array}$ & $34.23^{\mathrm{ab}}$ & $1.25^{\mathrm{ij}}$ & $0.40^{\mathrm{i}}$ & $1.641^{\mathrm{i}}$ \\
\hline $\mathbf{T}_{3}$ & $\begin{array}{l}\text { Foliar application of LBD3 at } \\
6 \mathrm{ml} / 1\end{array}$ & $32.25^{\mathrm{bc}}$ & $1.46^{\mathrm{f}}$ & $0.51^{\mathrm{d}}$ & $1.96^{\mathrm{e}}$ \\
\hline $\mathbf{T}_{4}$ & $\begin{array}{l}\text { Foliar application of LBD12 } \\
\text { at } 0.5 \mathrm{ml} / 1\end{array}$ & $31.93^{\text {bcd }}$ & $1.30^{\mathrm{h}}$ & $0.42^{\mathrm{h}}$ & $1.88^{\mathrm{h}}$ \\
\hline $\mathbf{T}_{5}$ & $\begin{array}{l}\text { Foliar application of LBD12 } \\
\text { at } 1 \mathrm{ml} / 1\end{array}$ & $31.66^{\mathrm{bcd}}$ & $1.34^{\mathrm{g}}$ & $0.40^{\mathrm{ef}}$ & $1.74^{\mathrm{i}}$ \\
\hline $\mathbf{T}_{6}$ & $\begin{array}{l}\text { Foliar application of LBD12 } \\
\text { at } 1.5 \mathrm{ml} / 1\end{array}$ & $34.01^{\mathrm{b}}$ & $1.45^{\mathrm{f}}$ & $0.46^{\mathrm{e}}$ & $1.91^{\mathrm{g}}$ \\
\hline $\mathbf{T}_{7}$ & $\begin{array}{l}\text { Foliar application of LBS6 at } \\
0.5 \mathrm{ml} / 1\end{array}$ & $30.65^{\mathrm{cd}}$ & $1.55^{\mathrm{d}}$ & $0.46^{\mathrm{e}}$ & $2.01^{d}$ \\
\hline $\mathbf{T}_{8}$ & $\begin{array}{l}\text { Foliar application of LBS6 at } \\
1 \mathrm{ml} / 1\end{array}$ & $23.26^{\mathrm{h}}$ & $1.12^{\mathrm{k}}$ & $0.35^{\mathrm{k}}$ & $1.47^{\mathrm{n}}$ \\
\hline $\mathbf{T}_{9}$ & $\begin{array}{l}\text { Foliar application of LBS6 at } \\
1.5 \mathrm{ml} / 1\end{array}$ & $26.31^{\text {efg }}$ & $1.50^{\mathrm{e}}$ & $0.44^{\mathrm{f}}$ & $1.94^{\mathrm{f}}$ \\
\hline $\mathbf{T}_{10}$ & $\begin{array}{l}\text { Foliar application of LBS13 } \\
\text { at } 0.5 \mathrm{ml} / 1\end{array}$ & $27.25^{\mathrm{ef}}$ & $1.73^{b}$ & $0.52^{c}$ & $2.24^{\mathrm{b}}$ \\
\hline$T_{11}$ & $\begin{array}{l}\text { Foliar application of LBS13 } \\
\text { at } 1 \mathrm{ml} / 1\end{array}$ & $23.29^{\text {gh }}$ & $1.63^{\mathrm{c}}$ & $0.53^{\mathrm{b}}$ & $2.16^{\mathrm{c}}$ \\
\hline $\mathbf{T}_{12}$ & $\begin{array}{l}\text { Foliar application of LBS13 } \\
\text { at } 1.5 \mathrm{ml} / 1\end{array}$ & $24.27^{\text {tgh }}$ & $1.94^{\mathrm{a}}$ & $0.61^{\mathrm{a}}$ & $2.55^{\mathrm{a}}$ \\
\hline$T_{13}$ & Distilled water control & $29.12^{\text {de }}$ & $1.23^{\mathrm{j}}$ & $0.37^{j}$ & $1.60^{\mathrm{m}}$ \\
\hline \multirow[t]{4}{*}{$\mathbf{T}_{14}$} & Control & $30.53^{\mathrm{cd}}$ & $1.45^{\mathrm{f}}$ & $0.44^{\mathrm{f}}$ & $1.71^{\mathrm{j}}$ \\
\hline & F-test & $*$ & $*$ & $*$ & $*$ \\
\hline & SE.m \pm & 1.047 & 0.009 & 0.002 & 0.002 \\
\hline & $\mathrm{CD}$ at $5 \%$ & 3.045 & 0.027 & 0.005 & 0.007 \\
\hline
\end{tabular}

*Significant at $5 \%$, DAS- Days after spraying.

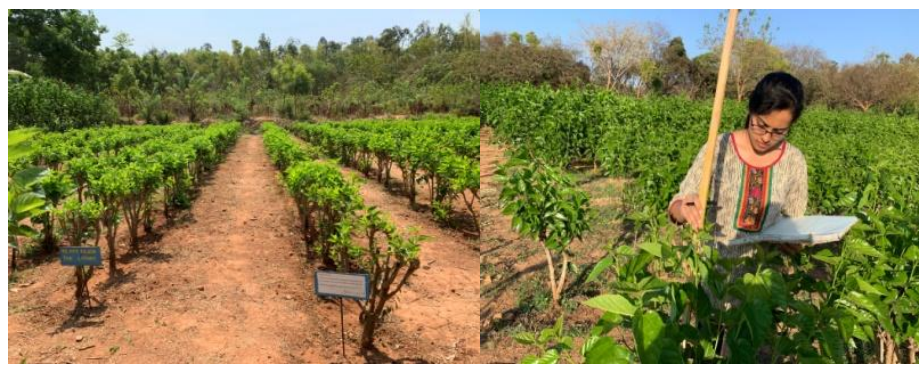




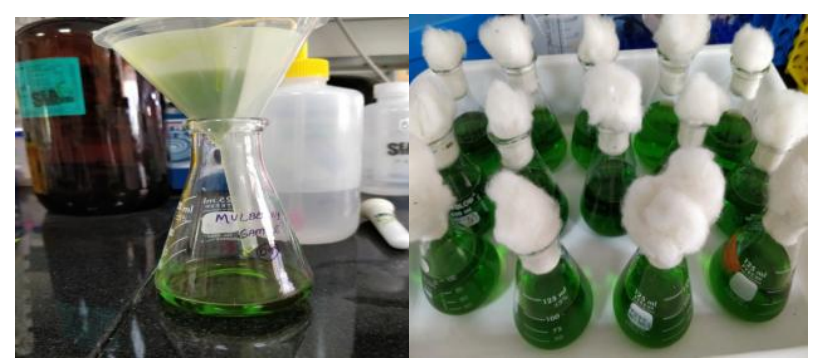

Estimation of chlorophyll

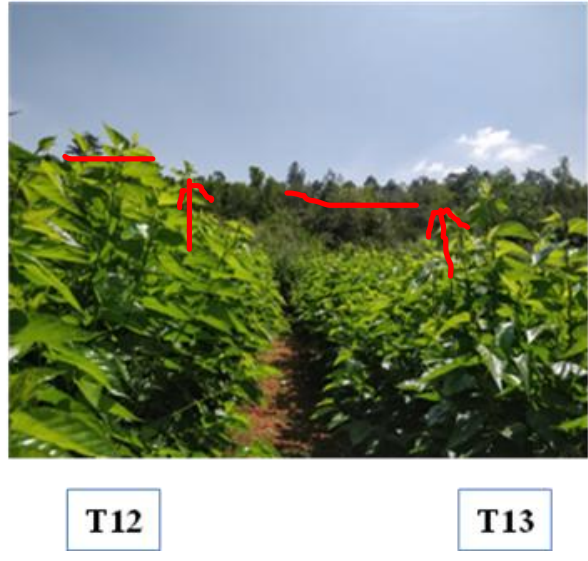

The treatment LBD3 at $2 \mathrm{ml} / \mathrm{l}$ was found to enhance the crude protein content of about $(37.21 \%)$ which was followed by LBD3 at 4 $\mathrm{ml} / \mathrm{l}(34.23 \%)$ and were on par with each other. Lesser crude protein content was recorded in the treatment LBS6 at $1 \mathrm{ml} / \mathrm{l}$ $(23.26 \%)$. The treatments LBD12 at $1.5 \mathrm{ml} / 1$ (34.01\%), LBD3 at $6 \mathrm{ml} / \mathrm{l}(32.25 \%), \mathrm{LBD} 12$ at $0.5 \mathrm{ml} / 1(31.93 \%)$ and LBD12 at $1 \mathrm{ml} / \mathrm{l}$ $(31.66 \%)$ also exhibited higher crude protein content when compared to that of the control $(30.53 \%)$ and were also on par with each other. (Mansori et al., 2015) in a grass trial application of seaplant extract (11.22lha $\left.{ }^{-1}\right)$, found significantly increased the content of crude protein over that of controls (91.1 against $84.1 \mathrm{~g} \mathrm{~kg}-1$ ); application of kinetin, at the same rate as in the seaweed extract, gave the same result.

The chlorophyll content was found to significantly increased in the treatment LBS13 at $1.5 \mathrm{ml} / 1$, where in chlorophyll ' $\mathrm{a}$ ' was $1.94 \mathrm{mg} / \mathrm{g}$, chlorophyll 'b' was $0.61 \mathrm{mg} / \mathrm{g}$

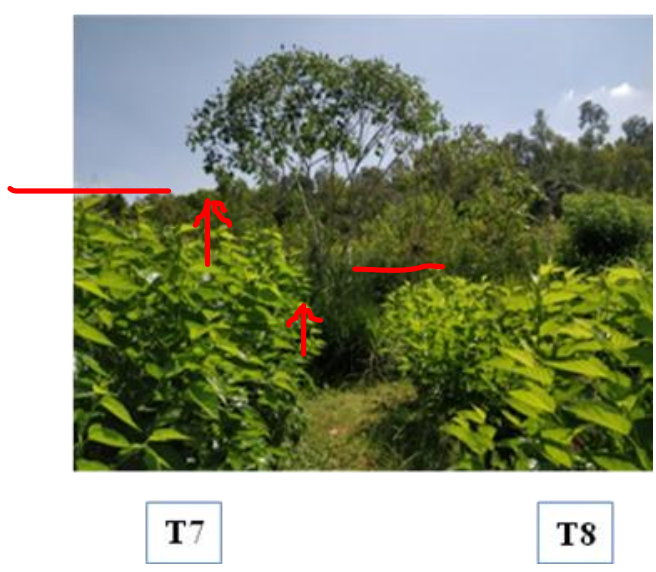

and total chlorophyll was found to be 2.55 $\mathrm{mg} / \mathrm{g}$. Least chlorophyll 'a', 'b' and total chlorophyll was noticed in LBS6 at $1 \mathrm{ml} / \mathrm{l}$ $(1.12 \mathrm{mg} / \mathrm{g}, \quad 0.35 \mathrm{mg} / \mathrm{g}$ and $1.47 \mathrm{mg} / \mathrm{g}$ respectively). The treatments LBS13 at $1 \mathrm{ml} / \mathrm{l}$ and LBS13 at $0.5 \mathrm{ml} / 1$ recorded increased chlorophyll content in all chlorophyll 'a' $(1.63 \mathrm{mg} / \mathrm{g}) \quad(1.73 \mathrm{mg} / \mathrm{g})$, 'b' (0.53 mg/g) $(0.52 \mathrm{mg} / \mathrm{g})$ and total chlorophyll $(2.16 \mathrm{mg} / \mathrm{g})$ $(2.24 \mathrm{mg} / \mathrm{g})$ respectively and were found to be higher than that of the absolute control (1.45 $\mathrm{mg} / \mathrm{g})(0.44 \mathrm{mg} / \mathrm{g})$ and $(1.71 \mathrm{mg} / \mathrm{g})$. Leaf chlorophyll concentration is an important parameter that is regularly measured as an indicator of chloroplast content, photosynthetic mechanism and plant metabolism. Seaplant products enhance plant chlorophyll content (Jayasinghe et al., 2016). Application of Ascophyllum nodosum at a lower concentration to soil or on the foliage of tomatoes produced leaves with enhanced chlorophyll content than those of the untreated and the enhanced chlorophyll content was a result of reduction in 
chlorophyll degradation, which might have resulted due to betaines in the seaweed extract (Shikha singh et al., 2016). Glycine betaine which will delay the loss of photosynthetic activity by not allowing the chlorophyll degradation during storage conditions in the isolated chloroplasts (Mansori et al., 2015).

In conclusion, the mulberry growth parameters such as plant height, number of shoots per plant, number of leaves per plant and leaf area were found higher than the control in Foliar application of LBS13 $(0.5,1$ and $1.5 \mathrm{ml} / \mathrm{l})$. The assessment of quality parameters of mulberry (LBD 3 and LBD 12) proved to increase the crude protein contents when compared to stimulants. There was a huge hike in the chlorophyll content of mulberry when treated with LBS 13 of all the three concentrations. These data depicts that the LBS will enhance the productivity of mulberry and also enhances the chlorophyll in the leaves which act as an indicator for the disease incidence in mulberry.

Leaf chlorophyll concentration is an important parameter that is regularly measured as an indicator of chloroplast content, photosynthetic mechanism and of plant metabolism. Since photosynthesis is enhanced via increasing a plants chlorophyll levels, mulberry can effectively utilize the sunlight increasing yield. Since seaweeds are collected in clean areas and the amounts of liquid extracts sprayed on the mulberry are small, the risk of dispersing heavy metals in the environment is negligible. Application of seaweed extracts can be beneficial for the growth and yield, the resistance to pests and diseases and the quality of crops. However, the bio stimulatory potential of many sea plants have not been fully exploited due to the lack of scientific data on growth factors present in seaweeds and also their mode of action in affecting growth of the plant.

\section{References}

Arnon, D. I., 1949, Copper enzymes in isolated chloroplasts. Polyphenoloxidase in Beta vulgaris. Plant Physiol., 24,1-15.

Arunkumar, K., Kamalarasan, M. and Archanadevi, J., 2015, Growth promoting effect of two seaweed extract on chilly, Capsicum annuum L.var. PMK 01. Phykos., 45(2):1-8.

Blunden, G., 1977, Cytokinin activity of seaweed extracts. In Marine Natural Products Chemistry (D.J. Faulkner \& W.H. Fenical, eds.), pp. 337-343. Plenum Publishing Corporation; New York.

Blunden, G., Jenkins, T. and Liu, Y., 1997, Enhanced leaf chlorophyll levels in plants treated with seaweed extract. $J$ Appl Phycol., 8:535-543.

Dandin SB, Jayaswal J, Giridhar K, (2003) Handbook of Sericulture Technologies. CSB, Bangalore. P.73 - 95.

Durand, N., Briand, X. and Meyer, C., 2003, The effect of marine bioactive substances (NPRO) and exogenous cytokinins on nitrate reductase activity in Arabidopsis thaliana., Physiol Plant, 119:489-493.

Featonby Smith, B. C., 1984, Cytokinins in Ecklonia maxima and the effect of seaweed concentrate on plant growth. Ph.D. thesis, University of Natal, Pietermaritzburg.

Ganesh, R. J., Doongar, R. C., Khadse, V. A. and Sudhakar, T. Z., 2015, Utilization of seaweeds in enhancing productivity and quality of black gram [Vigna mungo (L.) Hepper] for sustainable agriculture. Indian Journal of Natural Products and Resources, 6(1): 16-22.

Genard, H., Le Saos, J., Billard, J. P., Tremolieres, A. and Boucaud, J., 1991, Effect of salinity on lipid composition, glycine betaine content and photosynthetic activity in chloroplasts 
of Suaeda maritima. Plant Physiol Biochem., 29:421-427.

Jayasinghe, P. S., Pahalawattaarachchi, V. and Ranaweera, Kkds., 2016, Effect of Seaweed Liquid Fertilizer on Plant Growth of Capsicum annum. Discovery, 52(244): 723-734.

Khan, W., Rayirath, U. P., Jithesh, M. S., Rayorath, P., Hodges, D. M., Critchley, A. T., Craigie, J. S., Norrie, J. and Prithiviraj, B., 2009, Seaweed extracts as biostimulants of plant growth and development. J Plant Growth Regu., 28:386-399.

Lowry, O. H., Rosebrogh, N. J., Farr, A. L. and Randall, R. J., 1951, Protein measurement with the Folin phenol reagent. J. Biol. Chem., 193-265.

Maria Victorial Rani, S. and Michael Evanjaline, R., 2015, Effect of Kappaphycus alvaerezii SLF on Growth and Biochemicals in Morus Alba L. and Bombyx Mori L. International Journal of Research Studies in Biosciences, 3(12):47-52.

Ordog, V., Stirk, W. A., Van Staden, J., Novak, O. and Strnad, M., 2004, Endogenous cytokinins in the three genera of microalgae from the Chlorophyta. J Phycol., 40:88-95.

Rashmi. K., Shankar, M. A., Shashidhar, K. R. and Narayanaswamy, T. K., 2009, Growth and foliar constituents of mulberry (M5) cultivated under organic based nutrient management. Int.J.Indust.Entomol., 19 (1):165-169.

Stirk, W. A., Novak, M. S. and Van Staden, J., 2003, Cytokinins in macroalgae. Plant Growth Regul., 41:13-24.

Tiwary, P. K., Ghosh, M. K. and Nirmal Kumar, S., 2014, Effect of foliar application of seaweed extracts on quality and quantity improvement in mulberry. 23rd international congress on sericulture and silk industry, pp-14.

Vijaya, D., Yeledhalli, N. A., Ravi, M. V, Nagangoud, A. and Nagalikar, V. P., 2009, Effect of fertilizer levels and foliar nutrients on M-5 mulberry leaf nutrient content, quality and cocoon production. Karnataka J. Agric. Sci., 22(5): 1006-1012.

Whapham, C. A., Blunden, G., Jenkins, T. and Hankins, S. D., 1993, Significance of betaines in the increased chlorophyll content of plants treated with seaweed extract. J Appl Phycol., 5:231-234.

Zhang, X. and Schmidt RE., 1997, The impact of growth regulators on the $\alpha$ tocopherol status in water-stressed Poa pratensis L. Int Turfgrass Res. J., 8:1364-1373.

Zodape, S. T., 2001, Seaweeds as a biofertilizer. J. Sci. Ind. Res., 60(1): $378-382$.

\section{How to cite this article:}

Yeshika, M. P., K. G. Banuprakash, N. Nagaraju, Manjunath Gowda, K. Murali Mohan and Vinoda, K. S. 2020. Role of Sea Plant Extracts in Growth and Development of Mulberry for Sustainable Sericulture. Int.J.Curr.Microbiol.App.Sci. 9(09): 3670-3678. doi: https://doi.org/10.20546/ijcmas.2020.909.453 